\title{
Interactions between whey protein or polymerized whey protein and soybean lecithin in model system
}

\author{
X. M. Sun, ${ }^{*}$ C. N. Wang, ${ }^{* 1}$ and M. R. Guo ${ }^{*}+\ddagger^{1}$ \\ *Department of Food Science, College of Food Science and Engineering, Jilin University, Changchun, Jilin, 130062, China \\ †Department of Nutrition and Food Sciences, College of Agricultural and Life Sciences, University of Vermont, Burlington 05405 \\ łDepartment of Food Science, Northeast Agriculture University, Harbin, Heilongjiang, 150030, China
}

\section{ABSTRACT}

Soybean lecithin is often used as a surfactant in food formulation. The aim of this study was to investigate the interactions between soybean lecithin (SL, 0-3\%, wt/vol) and whey protein (WP, 10\%, wt/vol) or polymerized whey protein (PWP, 10\%, wt/vol) induced by heating WP solutions at $85^{\circ} \mathrm{C}$ for 0 to $20 \mathrm{~min}$ at $\mathrm{pH}$ 7.0. The samples were evaluated for zeta potential, particle size, morphology, rheological properties, thermal properties, secondary structure, and surface hydrophobicity. Zeta potential of WP increased linearly as SL level increased from 0 to $3 \%$, whereas that of PWP changed with plateau at SL level of $1 \%$, which may be due to the aggregation of SL. The addition of SL increased the particle size and apparent viscosity of both WP and PWP. All the samples exhibited different morphology depending on SL level and heating time according to transmission electron microscopy images. Whey protein showed obviously decreased gelation time and increased storage modulus in the presence of SL. Differential scanning calorimetry curves confirmed the effects of SL on the thermal properties of both WP and PWP. Circular dichroism spectra indicated that SL had effects on the secondary structure of both WP and PWP. The changes in surface hydrophobicity indicated the hydrophobic interactions between WP/PWP and SL. Data indicate that the physicochemical and functional properties of WP and PWP can be altered by adding soybean lecithin.

Key words: soybean lecithin, whey protein, physicochemical properties, functional properties, structural properties

\footnotetext{
Received May 2, 2018.

Accepted July 17, 2018

${ }^{1}$ Corresponding authors: wangcuina@jlu.edu.cn and mguo@uvm .edu
}

\section{INTRODUCTION}

Whey protein (WP) has been used in food industry as gelling agent, emulsifier, texture modifier, thickening agent (Wang et al., 2015), and foaming agent (Ikeda and Foegeding, 1999a) due to its various functional properties. Whey protein is a family of globular proteins. $\beta$-Lactoglobulin $(50-60 \%)$ is the main protein, and $\alpha$-LA $(\sim 20 \%)$ is the second most abundant protein (Liu et al., 2005). $\beta$-Lactoglobulin has 2 disulfide bonds and 1 free thiol group, which is responsible for the formation of polymerized whey protein (PWP; Andoyo et al., 2015). During heating, whey proteins (WP) unfolded and exposed groups such as hydrophobic amino acids and sulfhydryl groups, which were embedded initially. Then, the unfolded WP molecules aggregated through intermolecular interactions (e.g., hydrophobic interaction, disulfide bonding, and electrostatic interaction; Kinsella and Whitehead, 1989). The properties of PWP can be influenced by several factors, including protein level (Nicolai et al., 2011), heat treatment, salt type and level (Ikeda and Foegeding, 1999a,b), pH value (Li and Zhong, 2016), and addition of other ingredients such as surfactants (Viseu et al., 2007).

Surfactants are compounds that can lower the surface tension (or interfacial tension) between liquids or between liquid and solid. There are generally 4 types of surfactants: anionic (e.g., SDS), cationic [e.g., alkyl trimethyl ammonium chlorides (xTAC)], nonionic (e.g., Tween), and zwitterionic (e.g., lecithin) according to the charge type of hydrophilic head groups (Viseu et al., 2007). The interactions between proteins and surfactants have attracted the interest of many researchers because of their biotechnological and industrial applications (Kumar et al., 2015). Studies showed that surfactants could affect the aggregation process of proteins to various extents in different mechanisms. The interactions between biopolymers and surfactants can be affected by the type of reactants, medium, $\mathrm{pH}$, ionic strength, and temperature (Taheri-Kafrani et al., 2010). Anionic and nonionic surfactants can reduce the 
aggregation of proteins, whereas cationic surfactants can promote the process (Viseu et al., 2007).

Soybean lecithin (SL) is a mixture of phospholipid derivatives including phosphatidylcholine, phosphatidylethanolamine, phosphatidylserine, phosphatidylinositol, and phosphatidylglycerol (Miyasaki et al., 2015). Lecithin has both hydrophilic and lipophilic properties, and its hydrophobic groups tend to absorb to the surface of proteins with hydrophobic groups, whereas its hydrophilic heads face water to promote dispersion (Chiplunkar and Pratap, 2017). Therefore, it is not only a functional ingredient, but also can change surface activity including flexibility and hydrophobicity to improve dispersing and instant dissolving properties of protein powder during manufacturing (Vissotto et al., 2006; Li et al., 2014). However, few data are available on interactions between WP or PWP and SL because interactions between protein and surfactant mostly focused on anionic, cationic, and nonionic surfactants. The aim of this study was to investigate the interactions between SL and WP or PWP by measuring zeta potential, particle size, morphology, rheological properties, thermal properties, secondary structure, and surface hydrophobicity.

\section{MATERIALS AND METHODS}

\section{Materials}

Whey protein isolate (WPI) powder was purchased from Fonterra Co-operative Group (Auckland, New Zealand). It contained $92 \%$ (wt/wt) protein, $0.07 \%$ (wt/ wt) calcium, $0.04 \%$ (wt/wt) phosphorus, $0.57 \%$ (wt/ wt) sodium, and $0.04 \%$ (wt/wt) potassium as stated by the manufacturer. According to the manufacturer, soybean lecithin (Kemai Biochemical, Changchun, China) contains $60 \%$ (wt/wt) phosphatidylcholine, $18 \%$ (wt/ wt) phosphatidylinositol, $4.2 \%$ (wt/wt) phosphatidylethanolamine, $4 \%$ (wt/wt), phosphatidic acid, $5 \%$ (wt/ wt) lyso-lecithin (LPC, LPI, LPE, and LPA), $2 \%$ (wt/ wt) moisture, and 3\% (wt/wt) oil. Ultrapure water was prepared by a Millipore Milli-Q water purification system (Millipore Corp., Milford, MA). All other chemicals were reagent grade and purchased from Sigma (St. Louis, MO).

\section{Sample Preparation}

Solutions containing $10 \%$ (wt/vol) WP and $0.25-3 \%$ (wt/vol) SL, $10 \%$ (wt/vol) WP, and 0.25 to $3 \%$ (wt/ vol) SL were prepared with ultrapure water and stirred at 2,000 rpm for $2 \mathrm{~h}$ at ambient temperature with CMAG HS7 Magnetic Stirrers (IKA, Staufen, Germany).
To ensure the complete hydration, WP, WP-SL, and SL solutions were stored overnight at $4^{\circ} \mathrm{C}$ and then adjusted to $\mathrm{pH} 7.0$ with $1 \mathrm{M} \mathrm{NaOH}$ at room temperature. Part of unheated solutions was preserved for subsequent determination and the rest was heated in an $85^{\circ} \mathrm{C}$ water bath with constant stirring for 10 and 20 min, respectively. The PWP, SL, and mixtures of PWP and SL were obtained after cooling heated solutions to room temperature. The mixtures of WP and SL, and PWP and SL are expressed as WP-SL and PWP-SL, respectively.

\section{Zeta Potential and Particle Size Measurement}

All the solutions were diluted 10 and 100 times, respectively, in ultrapure water and vortexed for $30 \mathrm{~s}$ with an MS 3 basic vortex mixer (IKA, Staufen, Germany). The surface electric charge density of samples diluted 10 times and particle size of samples diluted 100 times were determined in disposable zeta cell and size cell (Zetasizer Nano-ZS, Malvern Instruments Ltd., Malvern, Worcestershire, UK) at $25^{\circ} \mathrm{C}$. Results were expressed as the average of 9 successive measurements.

\section{Transmission Electron Microscopy Analysis}

The morphology of samples was observed according to the method of Loiseleux et al. (2017) with some modifications. Samples were diluted using ultrapure water to $0.1 \%$ (wt/vol) concentration. A droplet $(\sim 10$ $\mu \mathrm{L}$ ) was put onto a carbon film supported by a $\mathrm{Cu}$ grid. The excess solution was removed with a filter paper after 1 min. The sample was then stained with $2 \%$ (wt/ vol) uranyl acetate solution for 2 min and dried at room temperature. Morphology images of samples were obtained by an H-7650 Transmission Electron Microscope (Hitachi High-Technologies, Tokyo, Japan) operated at a $100-\mathrm{kV}$ acceleration voltage.

\section{Rheological Properties Measurement}

A Discovery HR-1 Hybrid Rheometer (TA Instruments, New Castle, DE) fitted with a cooling system (Thermo Cube) was used to determine the apparent viscosity $(\eta)$ and dynamic oscillatory rheology of all samples using a $60-\mathrm{mm}$ diameter concentric cylinder geometry. Apparent viscosity was determined through flow frequency ramp test with the shear rate from 0.01 to $400 \mathrm{~s}^{-1}$ with the gap width of $1,000 \mu \mathrm{m}$. Dynamic rheological properties of samples were also studied. The unheated samples were heated from 25 to $85^{\circ} \mathrm{C}$ at $2.5^{\circ} \mathrm{C} / \mathrm{min}$, held at $85^{\circ} \mathrm{C}$ for $50 \mathrm{~min}$, and then cooled to $25^{\circ} \mathrm{C}$ at $1^{\circ} \mathrm{C} / \mathrm{min}$ with the strain of $0.1 \%$. The exposed 
edges of samples were coated with a thin layer of silicon oil before thermal protocol to prevent evaporation. The gelation time during the temperature ramp process was analyzed by the software Trios v3, 2.0.3877 (TA Instruments). Frequency sweep test was performed following the oscillation temperature ramp test in the range of 2 to $20 \mathrm{~Hz}$ to investigate the structure of the gels using a strain of $1 \%$ at $25^{\circ} \mathrm{C}$.

\section{Differential Scanning Calorimetry Assays}

Part of each sample was freeze-dried at $-55^{\circ} \mathrm{C}, 0.034$ $\mathrm{MPa}$ for $24 \mathrm{~h}$ by a freeze-dryer (Alpha 1-2, Marin Christ Inc., Osterode, Germany). Thermal analysis for freeze-dried samples was carried out using Q2000 differential scanning calorimetry (DSC; TA Instruments) according to the method described by previous study (Kumar et al., 2015) with some modifications. Briefly, a 5 to $10 \mathrm{mg}$ sample was placed in an aluminum pan (Tzero Pan, TA Instruments) and sealed with an aluminum hermetic lid (Tzero Aluminum lid, TA Instruments). A closed pan without sample was also put in the differential scanning calorimeter unit as a reference. The heating procedure was set from 20 to $260^{\circ} \mathrm{C}$ with a heating rate of $5^{\circ} \mathrm{C} / \mathrm{min}$. The nitrogen gas with a flow rate of $30 \mathrm{~mL} / \mathrm{min}$ was used to purge the sample holder. The onset temperature $\left(\mathrm{T}_{\mathrm{on}}\right)$ and the peak temperature $\left(T_{p}\right)$ of the transitions, as well as the glass transition temperature $\left(\mathrm{T}_{\mathrm{g}}\right)$ were obtained with Universal Analysis Software 3.9A (TA Instruments, New Castle, DE). Each sample was replicated 3 times.

\section{Far-UV Circular Dichroism Spectrum}

The circular dichroism (CD) spectra of $0.1 \mathrm{mg} /$ $\mathrm{mL}$ of WP, WP-SL, PWP, and PWP-SL dispersions were obtained in the spectral range of 190 to $260 \mathrm{~nm}$ by a MOS-500 spectrometer (Bio-Logic Science Ins., Seyssinet-Pariset, France) at $25^{\circ} \mathrm{C}$. A quartz cuvette (Starna Scientific Ltd., Essex, UK) was used and the optical path was $0.1 \mathrm{~cm}$. The ultrapure water was used as a blank. The content of secondary structures including $\alpha$-helix, $\beta$-strands, $\beta$-turns, and random coil were calculated using CONTIN (DichroWeb; http:// dichroweb.cryst.bbk.ac.uk/html/home.shtml), which fits the CD of unknown proteins by a linear combination of the spectra using a large database of proteins with known conformations (Chandrapala et al., 2011). Mean residue weight was estimated as $114 \mathrm{Da}$ based on the molecular masses of the 3 major components: $\beta$-LG, $\alpha$-LA, and BSA (Mantovani et al., 2016).

\section{Fluorescence Measurement}

Surface hydrophobicity was monitored by fluorescence spectra using 8-anilino-1-naphthalene sulfonic acid according to the method reported by Kato and Nakai (1980) with some modifications. Sample solutions were diluted with $0.01 M$ phosphate buffer (pH 7.0) to the level of $0.005 \%$ (wt/vol). The 8-anilino-1-naphthalene sulfonic acid stock solution $(8 \mathrm{~m} M)$ was prepared in 0.1 $M$ phosphate buffer ( $\mathrm{pH} 7.0)$; a portion $(20 \mu \mathrm{L})$ was added into $4 \mathrm{~mL}$ of diluted solution. The mixtures were kept in the dark for 3 min after being vortexed for 10 $\mathrm{s}$ before measurement. Fluorescence emission spectra were captured using a RF-5301PC Spectrofluorometer (Shimadzu Corp., Tokyo, Japan) with excitation wavelength of $390 \mathrm{~nm}$ and emission wavelength from 400 to $750 \mathrm{~nm}$, respectively; the width of the excitation and emission slits was set at $5 \mathrm{~nm}$. Measurements were made at least in triplicates for all samples.

\section{Statistical Analysis}

Statistical analysis was performed using SPSS 20.0 (SPSS Inc., Chicago, IL). One-way ANOVA was carried out and Tukey's test was applied to evaluate significant differences between the mean values $(P<0.05)$.

\section{RESULTS AND DISCUSSION}

\section{Zeta Potential of WP or PWP in the Presence of SL}

Zeta potential is an indicator for stability of protein solution by surface charge density. Zeta-potential values lower than $-10 \mathrm{mV}$ (usually between -25 and -30 $\mathrm{mV}$ ) can predict good stability due to the high-energy barrier between particles (Sui et al., 2017). Figure 1 showed the effects of SL on zeta potential of WP and PWP solutions. The zeta potential values for SL $(0.1 \%$, wt/vol) unheated, and heated for 10 and $20 \mathrm{~min}$ were $-69.57 \pm 2.06,-80.23 \pm 2.05$, and $-78.1 \pm 2.51 \mathrm{mV}$, respectively. Zeta potential of WP solution was -23.91 $\pm 2.08 \mathrm{mV}$. The negative charge of WP at neutral $\mathrm{pH}$ was also reported by previous study ( $\mathrm{Li}$ and Mcclements, 2013). The WP-SL samples showed more negative zeta potential from $-40.87 \pm 1.79$ to $-59.93 \pm$ $1.17 \mathrm{mV}$ when SL level increased from 1 to $3 \%$ (wt/ vol). It was reported that surfactants could bind and initiate protein unfolding by enhanced intra- and intermolecular electrostatic attraction and hydrophobic interactions (Jones, 1992). The binding of SL could induce the unfolding of WP conformation (Kwaambwa and Rennie, 2012), and increase the exposed negatively 


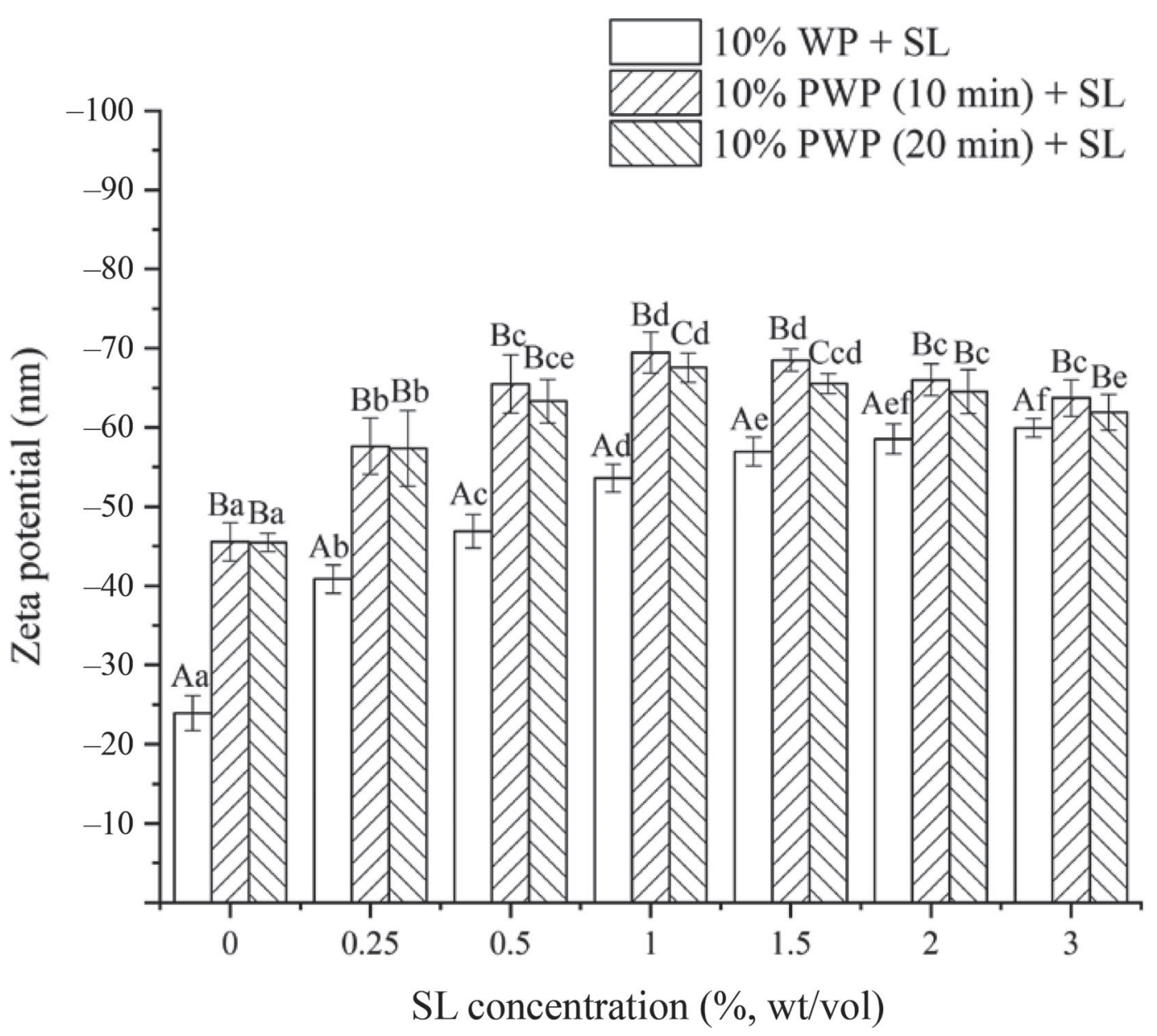

Figure 1. Effects of soybean lecithin $(0-3 \%$, wt/vol) on zeta potential of whey protein (WP) or polymerized whey protein (PWP; $10 \%$, wt/vol). Different lowercase letters denote a significant difference between WP or PWP with various soybean lecithin (SL) levels at $P<0.05$. Different uppercase letters denote a significant difference between samples at different heating times at $P<0.05$. Error bars represent SD of the mean.

charged residues, which was responsible for the gradually decreased zeta potential values. Similar results were reported by Wang et al. (2017b).

The PWP showed higher negative charges but no significant difference was observed between samples heated for different times $(P>0.05)$. The increment in absolute zeta potential of PWP could be observed when the level of SL increased from 0 to $1 \%$. Besides the electrostatic attraction and hydrophobic interactions between WP and SL that could induce the exposure of negative residues, heat treatment could also change the structure and expose inner groups of proteins (Bourbon et al., 2016). Zeta potential of PWP exhibited a minimum of $-69.44 \pm 2.61 \mathrm{mV}$ with $1 \% \mathrm{SL}$; the value increased with the increase in SL level. Similar zeta potential pattern of an emulsion containing WP and SL was reported by Wang et al. (2017b). The level of SL that induced the lowest zeta potential of protein solution was found $0.75 \%$ (wt/vol) in their study, which may be due to the different composition of sample solutions. We found that SL with higher level was promoting to aggregate and become a gel. Therefore, the zeta potential of PWP increased when the level of SL further increased from 1 to $3 \%$ was probably because more lecithin molecules displaced the WPI molecules and aggregated at the interface. As a result, some exposed residues were buried and could not contribute to the surface charge according to the previous study (Surh et al., 2006).

\section{Particle Size of WP or PWP in the Presence of SL}

The particle size of WP, WP-SL, PWP, and PWPSL were shown in Figure 2. The values for SL (0.1\%) unheated, and heated for 10 and $20 \mathrm{~min}$ were 690.47 $\pm 12.85,672.70 \pm 5.71$, and $651.53 \pm 10.47 \mathrm{~nm}$, re- 
spectively. An increment in particle size of unheated samples could be observed from $195.4 \pm 2.0$ to 1,114 $\pm 18.1 \mathrm{~nm}$ as SL level increased, which was due to the formation of large particles through the binding of WP and SL by electrostatic attraction.

Compared with native solutions, the particle size of all heated samples decreased sharply. During the unfolding of proteins caused by heating, the increased exposed hydrophobic residues could enhance the surface hydrophobicity of the protein, which could account for the diminished size of all PWP samples (Kinsella and Whitehead, 1989). The Dynamic light scattering determines the hydrodynamic size that corresponds to the core and the swollen corona of the particle. That is why the dynamic light scattering gives a larger size in native WP solution than PWP. Although not always significant, SL addition increased the particle sizes of
WP or PWP samples. The interactions between PWP and SL or formation of hydrogen bonds (Nicolai et al., 2011) may contribute to the increased size.

\section{Morphology of WP or PWP in the Presence of SL}

Transmission electron micrographs (Figure 3) were taken from solutions containing WP, SL, and WP-SL, as well as PWP and PWP-SL (20 min). The images presented remarkable differences depending on SL level and heat treatment. The particle size magnitudes were agreeable with Figure 2 determined by dynamic light scattering.

Protein particles in WP solution distributed uniformly. The increase in SL level contributed to the increase in particle size (Figure $3, \mathrm{~A}_{1}-\mathrm{A}_{4}$ ). Significantly larger particles could be observed when the level of SL

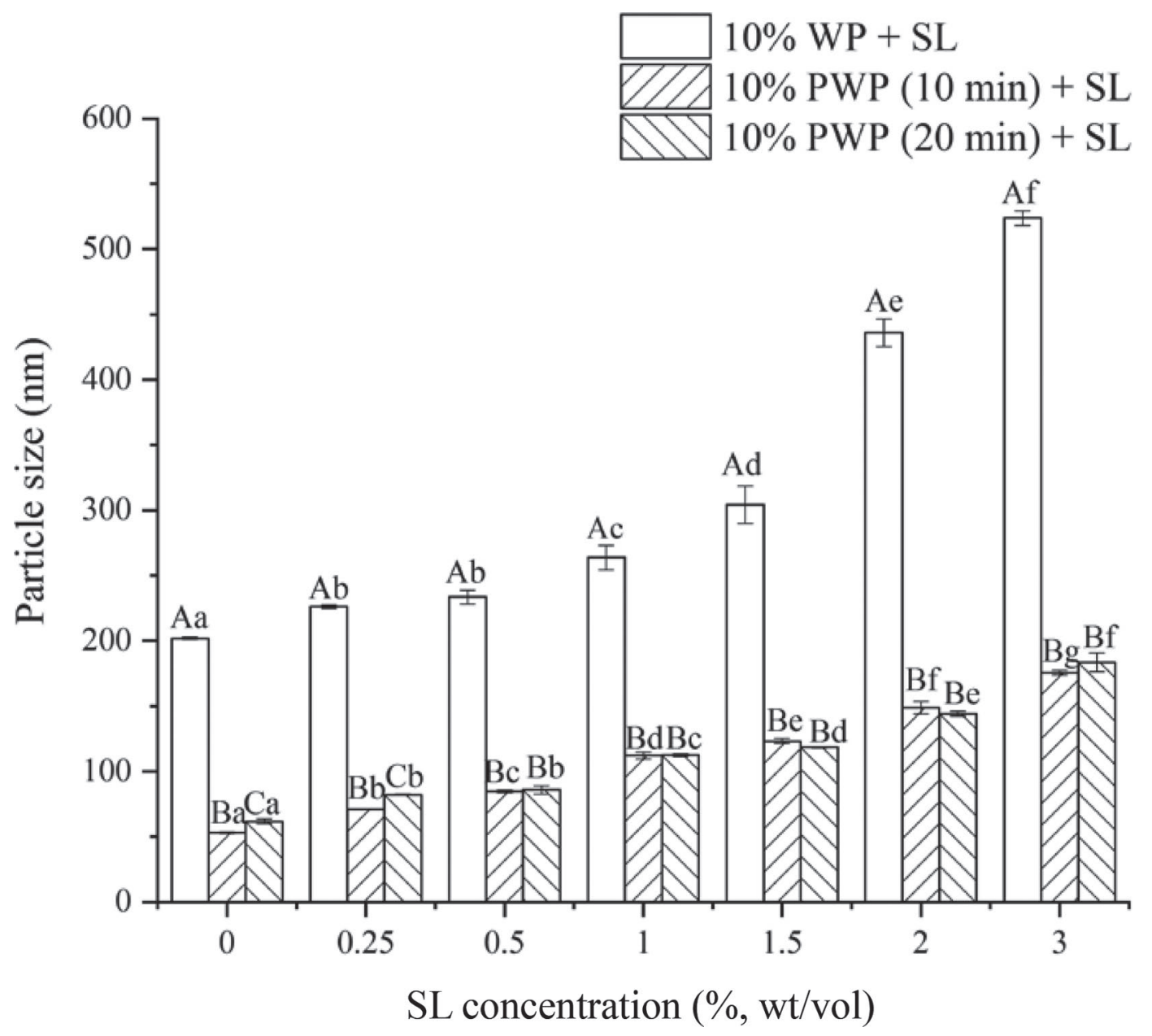

Figure 2. Effects of soybean lecithin (0-3\%, wt/vol) on particle size of whey protein (WP) or polymerized whey protein (PWP; 10\%, wt/vol). Different lowercase letters denote a significant difference between WP or PWP with various soybean lecithin (SL) levels at $P<0.05$. Different uppercase letters denote a significant difference between samples at different heating times at $P<0.05$. Error bars represent SD of the mean. 
increased to $3 \%$ (Figure $3, \mathrm{~A}_{4}$ ). The changes in the morphology of WP with various SL levels may also result from electrostatic attraction and hydrophobic interactions occurred between WP and SL as we discussed above.

After heating for $20 \mathrm{~min}$, particulate network formed during the aggregation of WP (Figure $3, \mathrm{~B}_{1}$ ). When the level of SL increased to $0.5 \%$, the network decreased significantly as shown in Figure $3 \mathrm{~B}_{2}$. However, no network could be observed and the particles got larger when the SL level reached $1 \%$. The diminished networks may be presumably due to the hydrophobic interactions between PWP and SL (Nicolai et al., 2011). As shown by Figure $3\left(\mathrm{~B}_{4}\right)$, when the SL level was $3 \%$, the clusters could be noticed after heating (Figure $3, \mathrm{~B}_{4}$ ). Similar

result was reported by previous study (Zhang et al., 2011). The changes in SL solutions shown in Figure 3, $\mathrm{C}_{1}-\mathrm{C}_{4}$, exhibited the similar morphology to those in PWP-SL samples. The morphology of SL was similar to that reported by Ding et al. (2015).

\section{Apparent Viscosity of WP or PWP in the Presence of $S L$}

Apparent viscosity $(\eta, \mathrm{mPa} \cdot \mathrm{s})$ of $\mathrm{WP}, \mathrm{WP}-\mathrm{SL}, \mathrm{PWP}$, and PWP-SL was determined as a function of shear rate $\left(0.01-400 \mathrm{~s}^{-1}\right)$, flow curves were shown in Figure 4. All samples showed shear-thinning behavior, especially in the shear rate range of 0 to $50 \mathrm{~s}^{-1}$, which could be attributed to deflocculating (Demetriades and Mccle-
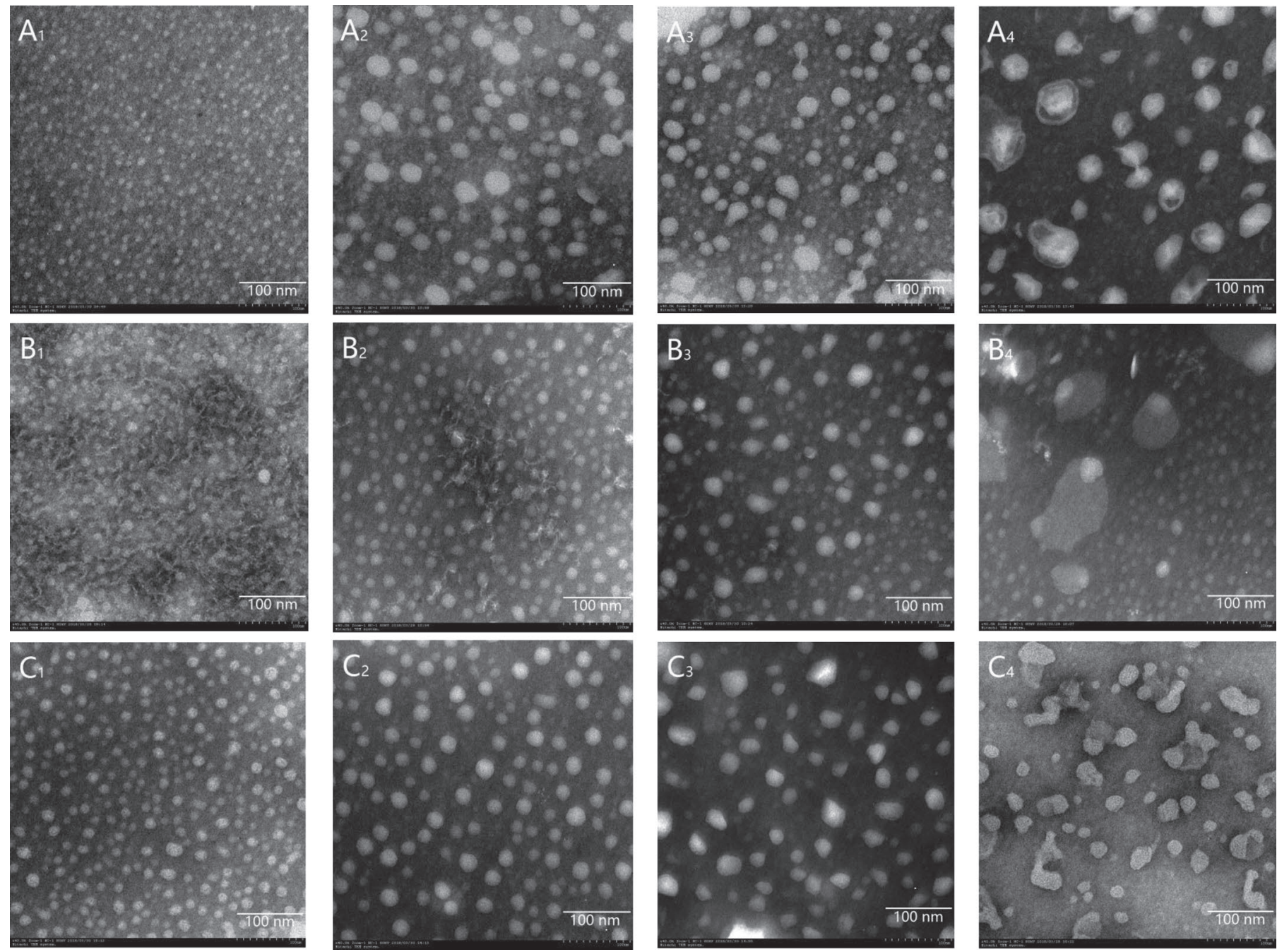

Figure 3. Transmission electron microscopy images of WP/WP-SL, PWP/PWP-SL heated for 20 min, and native SL and SL solutions heated for $20 \mathrm{~min}$. $\mathrm{WP}=$ whey protein; $\mathrm{SL}=$ soybean lecithin; $\mathrm{PWP}=$ polymerized whey protein. $\mathrm{A}_{1}: \mathrm{WP} ; \mathrm{A}_{2}: \mathrm{WP}+0.5 \% \mathrm{SL} ; \mathrm{A}_{3}: \mathrm{WP}+1 \%$ $\mathrm{SL} ; \mathrm{A}_{4}: \mathrm{WP}+3 \% \mathrm{SL} ; \mathrm{B}_{1}: \mathrm{PWP} ; \mathrm{B}_{2}: \mathrm{PWP}+0.5 \% \mathrm{SL} ; \mathrm{B}_{3}: \mathrm{PWP}+1 \% \mathrm{SL} ; \mathrm{B}_{4}: \mathrm{PWP}+3 \% \mathrm{SL} ; \mathrm{C}_{1}: 1 \%$ unheated SL; $\mathrm{C}_{2}: 0.5 \%$ heated SL; $\mathrm{C}_{3}:$ $1 \%$ heated SL; $\mathrm{C}_{4}: 3 \%$ heated SL. 


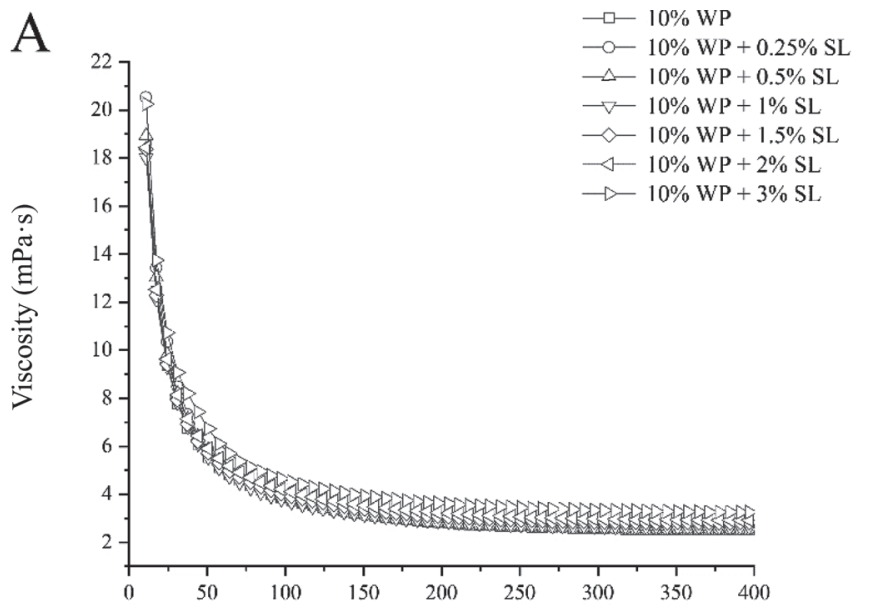

B
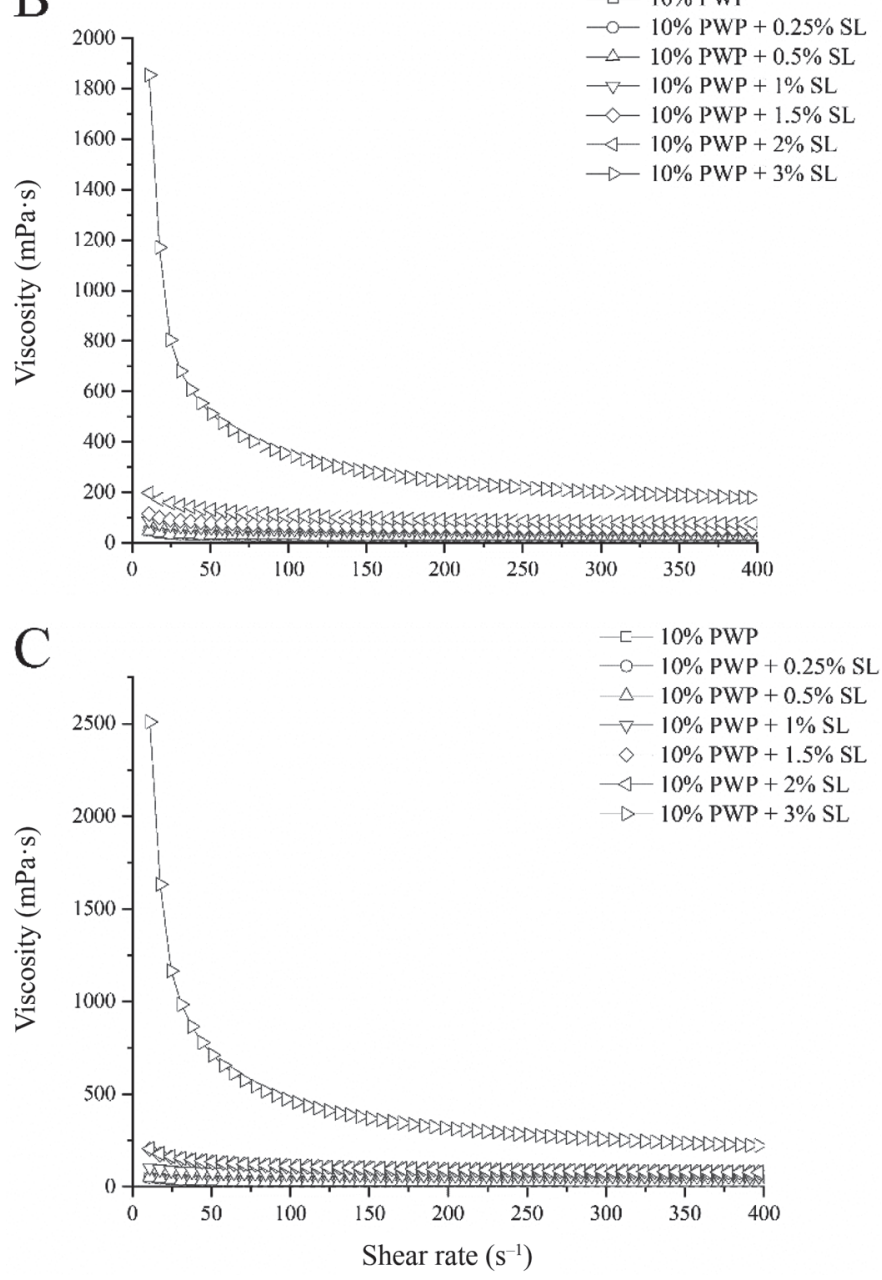

Figure 4. Effects of soybean lecithin (SL; 0-3\%, wt/vol) addition on apparent viscosity of whey protein (WP) or polymerized whey protein (PWP; 10\%, wt/vol), A: WP/WP-SL, B: PWP/PWP-SL heated for $10 \mathrm{~min}, \mathrm{C}$ : PWP/PWP-SL heated for $20 \mathrm{~min}$. ments, 1998). Sharp reduction at lower shear rates, followed by smooth curve at higher shear rates, were due to the deformation and reduction in aggregated particles (Lee and Choo, 2015).

The WP and WP-SL samples exhibited much lower viscosity than PWP and PWP-SL, which was in accordance with the previous study (Zhang and Vardhanabhuti, 2014). The increased SL level generated a slight increase in the apparent viscosity as shown in Figure 4A. The apparent viscosity of PWP and PWPSL became higher as function of heating time and SL level (Figure 4B and 4C). According to the previous study, hydrophobic associations play a role in molecular structuring (Eissa, 2013). After combining the results of transmission electron microscopy shown in Figure 3, it could be concluded that the hydrophobic interactions may be responsible for the increasing apparent viscosity by changing the conformation structure of PWP. Addition of $3 \%$ SL increased the apparent viscosity pronouncedly, which may be due to the aggregation of SL promoting the viscosity of PWP extensively.

\section{Oscillation Rheological Properties of WP or PWP in the Presence of SL}

Though interactions between WP and surfactants may occur at room temperature, they can only be obviously observed during thermal treatment (Le et al., 2011). Thermal gelation properties of WP in the presence of soybean lecithin were monitored by an oscillation rheology and results were shown in Figure 5A. Compared with storage modulus $\left(\mathbf{G}^{\prime}\right)$, loss modulus $\left(\mathbf{G}^{\prime \prime}\right)$ was ignored for simplicity due to the extremely small values (Homer et al., 2016). The WP-SL showed a much higher $G^{\prime}$ value than WP when the SL level was greater than $1 \%$ during the whole process. The sharp increase in $\mathrm{G}^{\prime}$ during holding and cooling steps indicated the establishment of gel network (Verheul and Roefs, 1999). The gelation temperature of WP was $85^{\circ} \mathrm{C}$ in this study. It was different from that of $78^{\circ} \mathrm{C}$ for $10 \%$ WP dispersions at $\mathrm{pH} 5.6$ reported by Ikeda and Foegeding (1999a). The observed higher gelation temperature may be due to the higher $\mathrm{pH}$ in this study, which is a critical factor influencing the gelation properties of WP (Demetriades and Mcclements, 1998). The SL did not change the gelation temperature of WP. However, it was noteworthy that SL level greater than $1 \%$ shortened the gelation time of WP pronouncedly. Compared with WP solution (3,218.16 s), WP with $1 \%$ and $3 \%$ SL showed decreased gelation time of 2,385.04 and $1,823.28 \mathrm{~s}$, respectively. Ikeda and Foegeding (1999a) also reported that lecithin accelerated the gelation rates of WP gels. 
To investigate the strength and viscous behavior of gels according to previous study (Tarhan et al., 2016), when samples cooled to $25^{\circ} \mathrm{C}, \mathrm{G}^{\prime}$ and $\mathrm{G}^{\prime \prime}$ were characterized by frequency sweep in the range of 2 to $20 \mathrm{~Hz}$, which was part of the viscoelastic region (Oechsle et al., 2015). Results are shown in Figure 3B. All samples exhibited frequency dependence on $\mathrm{G}^{\prime}$, which increased with the increasing frequency. It indicated that the gels might form via noncovalent hydrophobic interactions (Creusot and Gruppen, 2007). Addition of $0.25 \%$

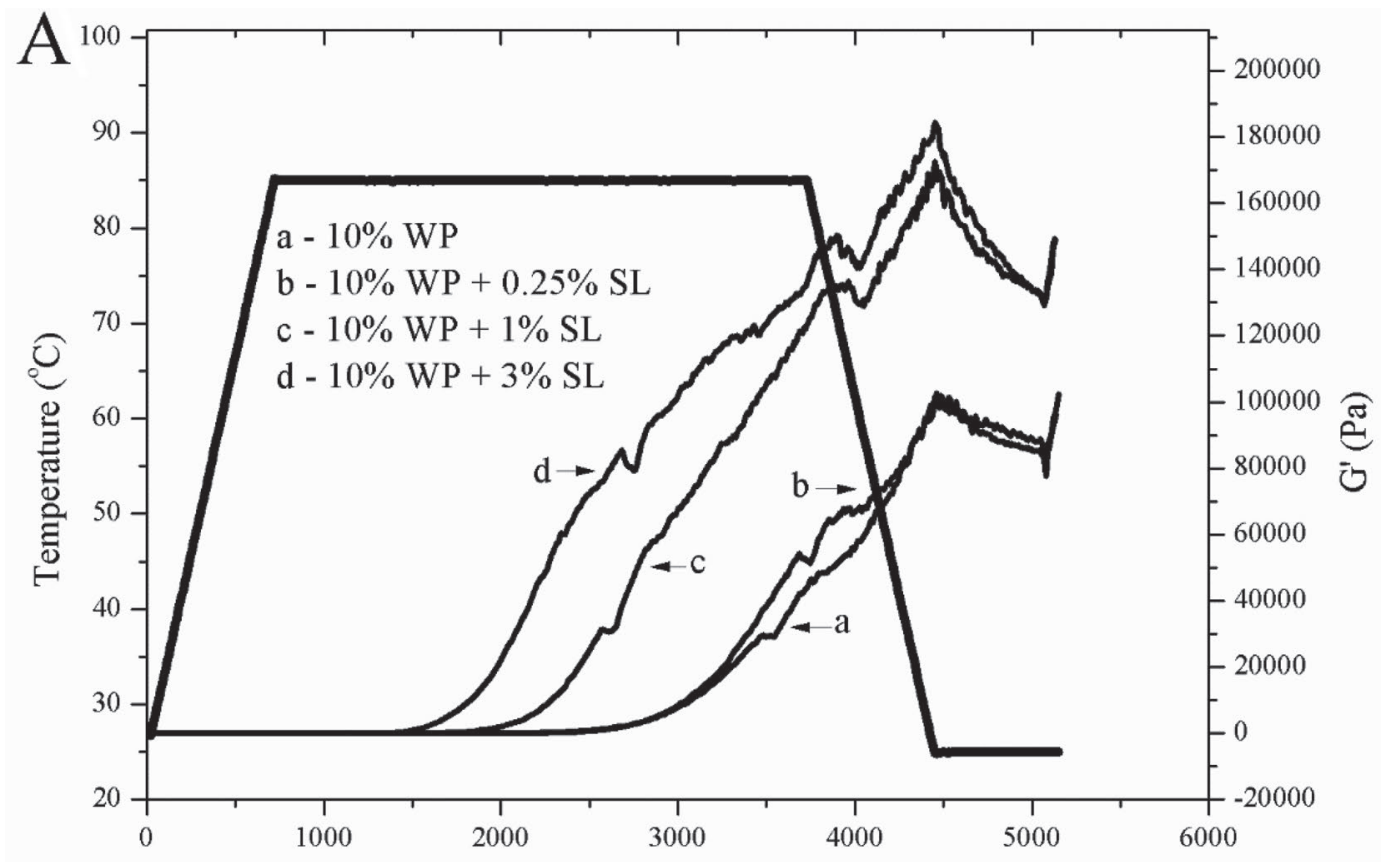

Time (s)

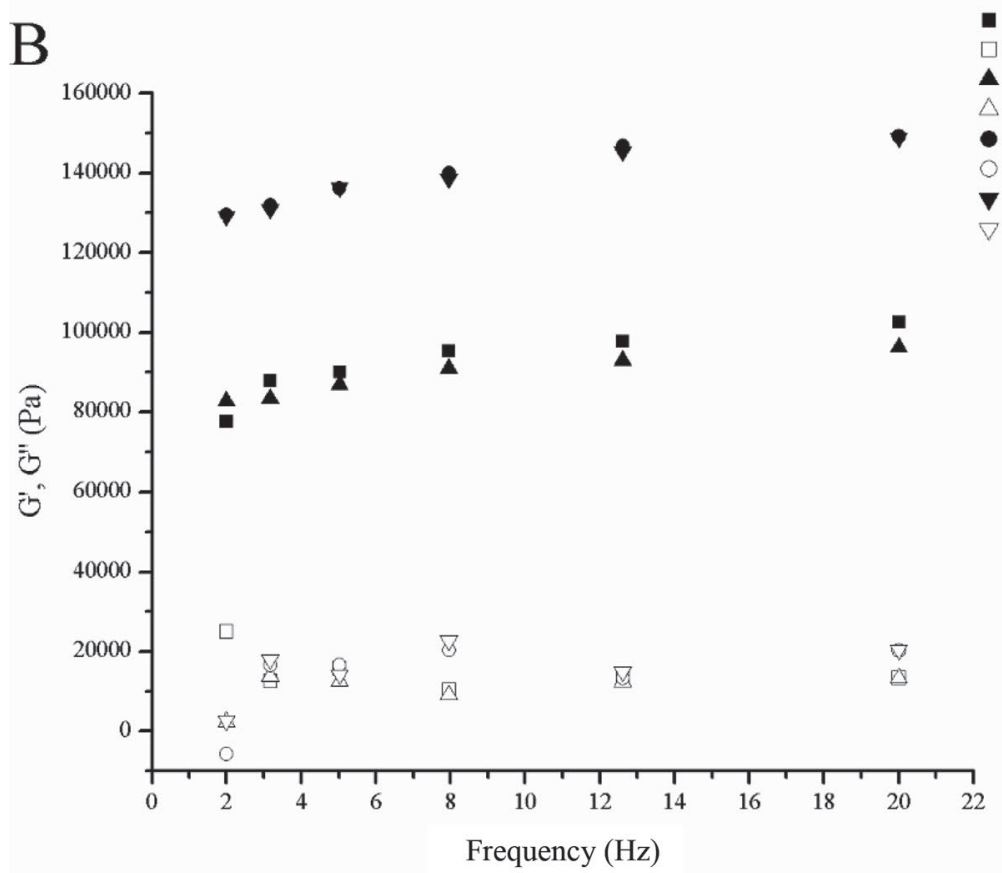

Figure 5. Effects of soybean lecithin (SL; 0.25, 1, and 3\%, wt/vol) addition on dynamic rheology of whey protein (WP; $10 \%$, wt/vol). G' = storage modulus; $\mathrm{G}^{\prime \prime}=$ loss modulus; WP = whey protein. 
SL did not change the $\mathrm{G}^{\prime}$ values of WP gel obviously. However, obvious higher $\mathrm{G}^{\prime}$ values could be observed for WP samples with both 1 and 3\% levels. Namely, addition of SL above $1 \%$ could increase the rigidity of WP gels.

\section{Thermal Properties of WP or PWP in the Presence of SL}

Thermal properties can reflect the chemical composition and structure of polymers (Ptiček Siročić et al., 2016). To study the effects of SL on the thermal properties of WP and PWP, DSC was performed and results are shown in Figure 6. Detected peaks were indicated with different letters (from a to d).

The curves for native samples were all composed of 2 endothermic transitions (peak a and b) and a glass

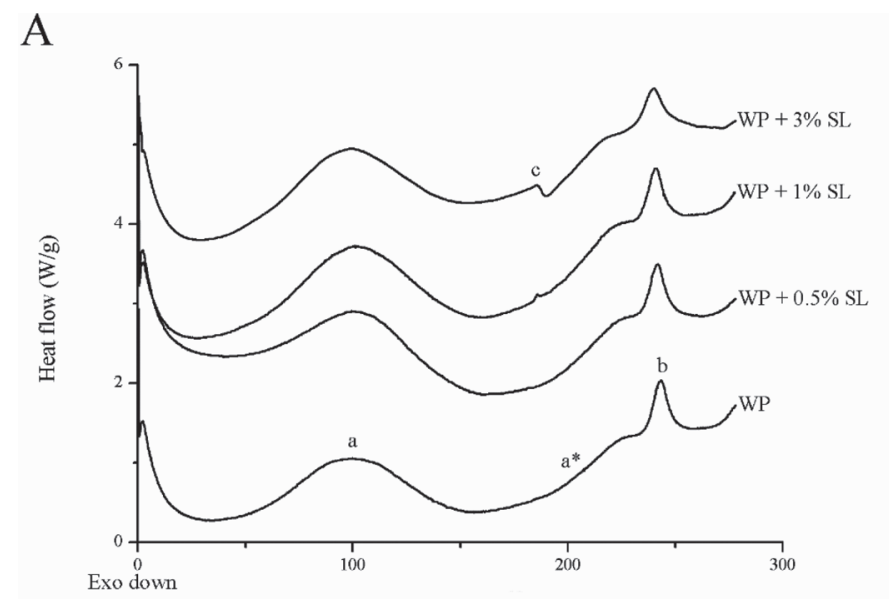

B

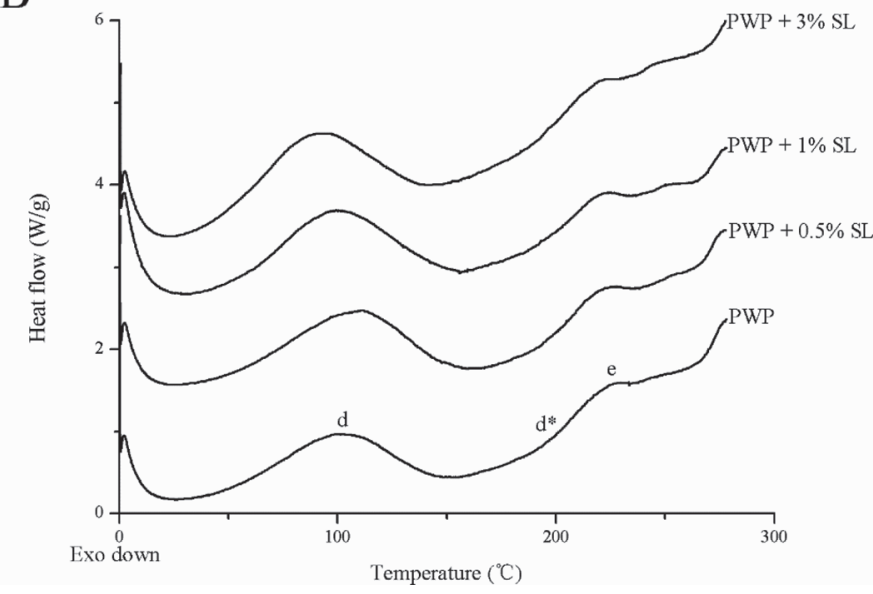

Figure 6. Effects of soybean lecithin (SL; 0.5, 1, and 3\%, wt/ vol) addition on thermal properties of whey protein (WP; 10\%, wt/ vol). $\mathrm{PWP}=$ polymerized whey protein. Endothermic transitions were marked with letters a to e, and glass transitions were marked with letter a and d with asterisks. transition $\left(\mathrm{a}^{*}\right)$ as shown in Figure 6A. It was reported that the denaturation temperature of WP was between 50 and $110^{\circ} \mathrm{C}$ (Fitzsimons et al., 2007). It could be concluded that endothermic transition a was related to the denaturation of WP. Peak b was probably associated with the decomposition of proteins according to the previous study (Pugliese et al., 2016). When the level of SL increased from 0.5 to $3 \%$, no significant difference occurred in the $\mathrm{T}_{\text {on }}$ and $\mathrm{T}_{\mathrm{p}}$ of peak $\mathrm{a}$, whereas the $\mathrm{T}_{\mathrm{g}}$ of glass transition a* decreased from 216.3 to $204.2^{\circ} \mathrm{C}$. The $\mathrm{T}_{\text {on }}$ value of endothermic transition $\mathrm{b}$ also decreased from 237.0 to $236.3,233.8,231.3^{\circ} \mathrm{C}$, and the $\mathrm{T}_{\mathrm{p}}$ value decreased from 243.4 to $241.7,240.8$, and $239.9^{\circ} \mathrm{C}$ as the level of SL increased from 0 to $0.5 \%, 1 \%$, and $3 \%$. Interestingly, a little endothermic transition (peak c) with the $\mathrm{T}_{\mathrm{on}}$ and $\mathrm{T}_{\mathrm{p}}$ around 172 and $185^{\circ} \mathrm{C}$ showed up on the curve of WP with 1 and $3 \%$ SL, which may be due to the denaturation of SL.

The PWP (20 min) also possessed endothermic transition a and glass transition $\mathrm{a}^{*}$ as shown in Figure 6B. Peak c disappeared, and the endothermic peak b of native samples was replaced by an exothermic transition d. It was reported that the glass transition $a^{*}$ along with the exothermic transition d was probably related to the formation of new structure (Thomas et al., 2004). The PWP samples exhibited lower $T_{\text {on }}$ values than the native samples. The increase in SL concentration diminished the $\mathrm{T}_{\text {on }}$ of the endothermic transition from 52.6 to $46.0^{\circ} \mathrm{C}$. The $\mathrm{T}_{\mathrm{g}}$ of heated samples were all around $208^{\circ} \mathrm{C}$. It could be concluded that the addition of SL could change the thermal properties of WP and PWP.

\section{Secondary Structure of WP or PWP in the Presence of $S L$}

Interactions between surfactants and proteins can induce changes in protein conformation (Kelley and Mcclements, 2003). As a technique for evaluating the secondary structure of proteins, CD spectroscopy can be used to investigate the interactions between proteins and other molecules (Bourbon et al., 2016). The effect of the addition of SL on the secondary structure of WP and PWP by heating for 20 min was investigated by CD spectroscopy (Figure 7). The content of the secondary structures were calculated and listed in Table 1 .

A broad depression with a minimum plateau from 208 to $222 \mathrm{~nm}$ and a zero crossing around $203 \mathrm{~nm}$, suggesting the predominant secondary structure conformation of $\alpha$-helix and $\beta$-sheet could be observed from WP and WP-SL samples (Taheri-Kafrani et al., 2010). Similar result was reported by Mantovani et al. (2016). Protein unfolding as a consequence of WP and 

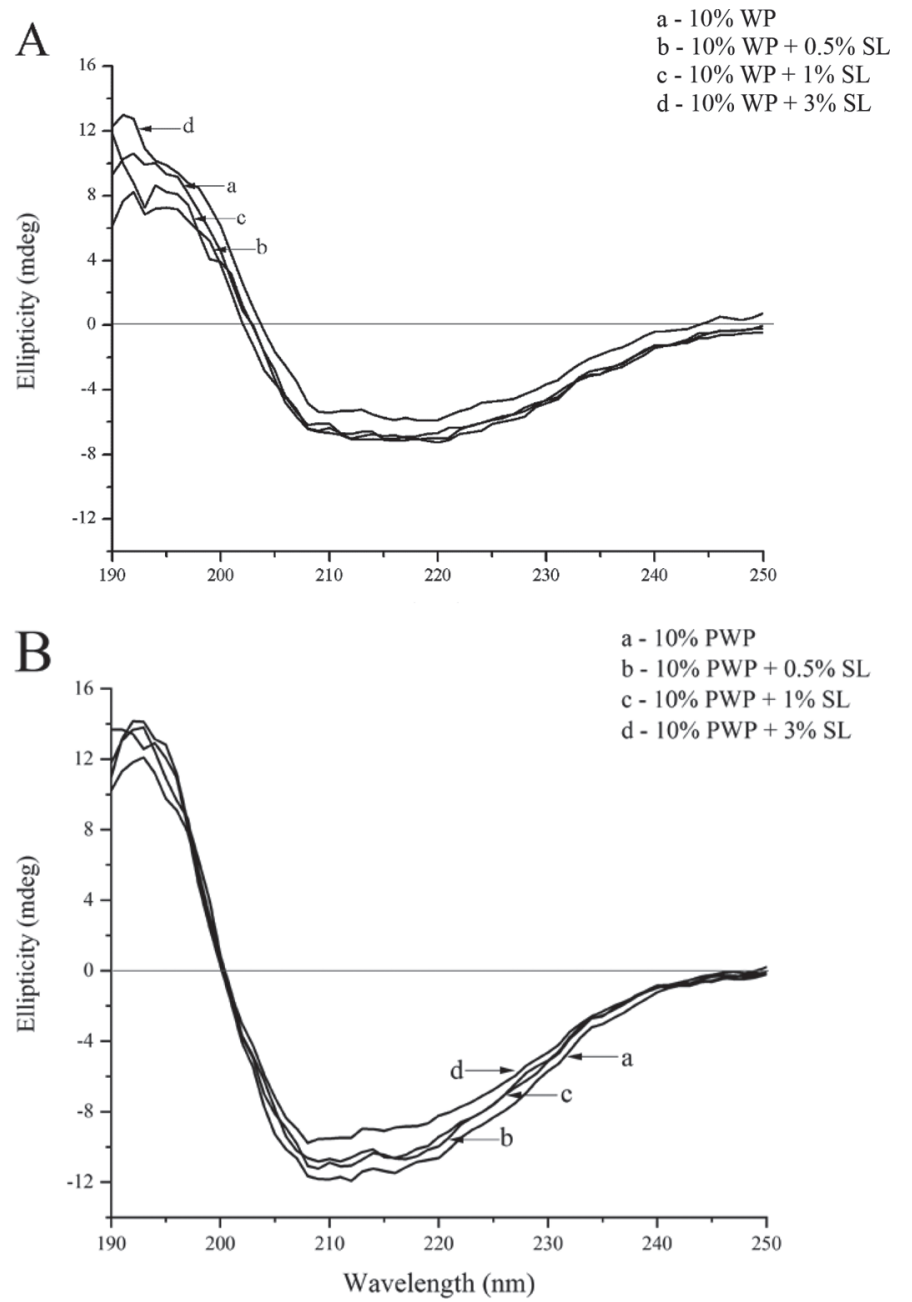

Figure 7. Effects of soybean lecithin $(0.5,1$, and $3 \%$, wt $/ \mathrm{vol})$ addition on circular dichroism spectra of whey protein (WP) or polymerized whey protein (PWP; $20 \mathrm{~min}, 10 \%$, wt/vol). SL = soybean lecithin.
SL interactions could be confirmed by the increase in $\alpha$-helix content $(10.1 \pm 0.3 \%$ to $23.9 \pm 1.0 \%)$ and the decrease in $\beta$-sheet content $(45.9 \pm 2.0 \%$ to $43.4 \pm$ $3.7 \%$ ) when the SL level increased from 0 to $1 \%$. The intensity of the transition from $\beta$-sheet to $\alpha$-helix was lower when the addition level of SL was $3 \%$.

Decrease in the ellipticity and zero crossing values could be observed from PWP heating for 20 min (Figure 7). In addition, PWP and PWP-SL samples exhibited significant higher $\alpha$-helix content at the expense of $\beta$-sheet content (Table 1). According to previous study, heat treatment could promote the $\beta \rightarrow \alpha$ transition during the unfolding process of protein secondary structure (Viseu et al., 2007). It was noted that addition of SL from 0 to $1 \%$ contributed to slightly decreases in $\alpha$-helix from $(29.3 \pm 2.0 \%$ to $28.5 \pm 1.9 \%)$ and unordered structures $(32.5 \pm 1.1 \%$ to $28.9 \pm 1.0 \%)$, as well as increases in $\beta$-sheet $(38.2 \pm 2.8 \%$ to 42.7 $\pm 3.3 \%$ ), which suggested that SL changed the secondary structures of PWP after heating. Interestingly, when SL level reached 3\%, the secondary structures of PWP exhibited lower $\alpha$-helix content $(26.5 \pm 1.1 \%)$ and $\beta$-sheet content $(41.4 \pm 2.7 \%)$, accompanied with the higher unordered structures. The aggregation of SL might increase the content of unordered structures of PWP at the expense of $\alpha$-helix and $\beta$-sheet.

\section{Surface Hydrophobicity of WP or PWP in the Presence of SL}

Thermal-induced aggregation of proteins is generally predominated by hydrophobic interaction (Ryan et al., 2012). Surface hydrophobicity can indicate the changes of protein macromolecular structure functionally $(\mathrm{Mu}-$ tilangi et al., 1996). Fluorescence spectrum was used to evaluate effects of SL (0-3\%) on surface hydrophobicity

Table 1. Effects of soybean lecithin (SL; $0.5,1$, and 3\%, wt/vol) level on secondary structures (\%) of whey protein (WP) or polymerized whey protein (PWP; 10\%, wt/vol) based on the CONTIN (DichroWeb; http:// dichroweb.cryst.bbk.ac.uk/html/home.shtml) program ( $\beta$-sheet is the sum of $\beta$-strand and $\beta$-turn)

\begin{tabular}{|c|c|c|c|c|}
\hline Sample name & $\alpha$-Helix & $\beta$-Strands & $\beta$-Turns & Unordered \\
\hline WP & $10.1 \pm 0.3^{\mathrm{A}, \mathrm{a}}$ & $30.2 \pm 1.7^{\mathrm{A}, \mathrm{a}}$ & $15.7 \pm 0.7^{\mathrm{A}, \mathrm{a}}$ & $44.0 \pm 1.6^{\mathrm{A}, \mathrm{a}}$ \\
\hline $\mathrm{WP}+0.5 \% \mathrm{SL}$ & $22.4 \pm 1.9^{\mathrm{A}, \mathrm{bcd}}$ & $26.2 \pm 1.3^{\mathrm{A}, \mathrm{b}}$ & $18.7 \pm 1.0^{\mathrm{A}, \mathrm{ab}}$ & $32.7 \pm 1.5^{\mathrm{A}, \mathrm{b}}$ \\
\hline $\mathrm{WP}+1 \% \mathrm{SL}$ & $23.9 \pm 1.0^{\mathrm{A}, \mathrm{bc}}$ & $23.8 \pm 1.5^{\mathrm{A}, \mathrm{b}}$ & $19.6 \pm 0.9^{\mathrm{A}, \mathrm{b}}$ & $32.7 \pm 1.4^{\mathrm{A}, \mathrm{b}}$ \\
\hline $\mathrm{WP}+3 \% \mathrm{SL}$ & $20.4 \pm 0.9^{\mathrm{A}, \mathrm{bd}}$ & $35.7 \pm 1.3^{\mathrm{A}, \mathrm{c}}$ & $19.6 \pm 1.5^{\mathrm{A}, \mathrm{b}}$ & $24.3 \pm 1.7^{\mathrm{A}, \mathrm{c}}$ \\
\hline PWP & $29.3 \pm 2.0^{\mathrm{B}, \mathrm{a}}$ & $19.2 \pm 0.8^{\mathrm{B}, \mathrm{a}}$ & $19.0 \pm 0.7^{\mathrm{A}, \mathrm{a}}$ & $32.5 \pm 1.1^{\mathrm{B}, \mathrm{ab}}$ \\
\hline $\mathrm{PWP}+0.5 \% \mathrm{SL}$ & $28.3 \pm 1.2^{\mathrm{B}, \mathrm{a}}$ & $20.9 \pm 1.1^{\mathrm{B}, \mathrm{a}}$ & $21.4 \pm 0.7^{\mathrm{A}, \mathrm{a}}$ & $29.4 \pm 1.5^{\mathrm{A}, \mathrm{abc}}$ \\
\hline $\mathrm{PWP}+1 \% \mathrm{SL}$ & $28.5 \pm 1.9^{\mathrm{B}, \mathrm{a}}$ & $22.2 \pm 1.1^{\mathrm{A}, \mathrm{a}}$ & $20.5 \pm 0.8^{\mathrm{A}, \mathrm{a}}$ & $28.9 \pm 1.0^{\mathrm{B}, \mathrm{bc}}$ \\
\hline $\mathrm{PWP}+3 \% \mathrm{SL}$ & $26.5 \pm 1.1^{\mathrm{B}, \mathrm{a}}$ & $21.6 \pm 0.9^{\mathrm{B}, \mathrm{a}}$ & $19.8 \pm 1.0^{\mathrm{A}, \mathrm{a}}$ & $32.1 \pm 1.3^{\mathrm{B}, \mathrm{abc}}$ \\
\hline
\end{tabular}



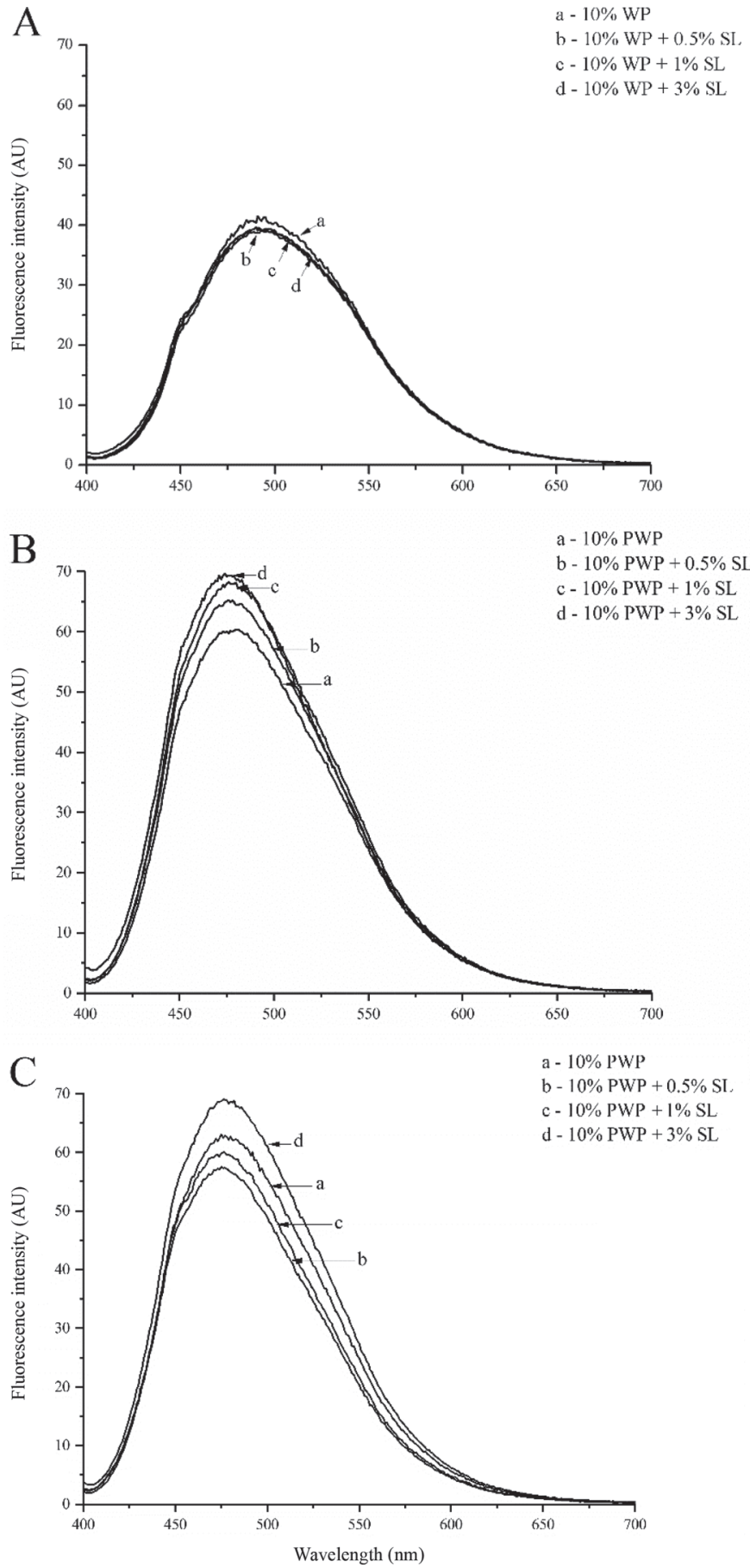

Figure 8. Effects of soybean lecithin $(0.5,1$, and $3 \%$, wt/vol) addition on surface hydrophobicity of whey protein (WP) or polymerized whey protein (PWP; 10\%, wt/vol). A: WP/WP-SL; B: PWP/ PWP-SL heated for $10 \mathrm{~min}$; C: PWP/PWP-SL heated for $20 \mathrm{~min}$. SL $=$ soybean lecithin.

of WP and PWP heated for 10 and $20 \mathrm{~min}$, and results were shown in Figure 8.

The WP-SL exhibited slightly lower fluorescence intensity than WP (Figure 8A). Hydrophobic interac- tions between WP and SL may be responsible for the decreased surface hydrophobicity of WP.

After heating for 10 and $20 \mathrm{~min}$ as shown in Figure $8 \mathrm{~B}$ and $8 \mathrm{C}$, all samples exhibited much higher fluorescence intensity than native samples. That was because the unfolding tertiary structures of WP might occur at $85^{\circ} \mathrm{C}$, which in consequence exposed the previously buried hydrophobic parts to the surface and increased the surface hydrophobicity (Sui et al., 2017). It could be obviously noted that the increase in SL level from 0 to $3 \%$ gave rise to the fluorescence intensity after heating for $10 \mathrm{~min}$ (Figure 8B), which indicated that SL could enhance the unfolding extent of protein and expose buried hydrophobic groups.

However, after heating for $20 \mathrm{~min}$, SL at different levels showed different changes in the surface hydrophobicity of PWP. The PWP with SL greater than 1\% showed higher surface hydrophobicity values, whereas $\mathrm{SL}$ in the range of 0 to $1 \%$ caused lower fluorescence values than PWP as shown in Figure 8. The decrease in surface hydrophobicity may be due to the hydrophobic interactions between PWP and SL promoted the aggregation of PWP and buried some hydrophobic residues (Nicolai et al., 2011). As discussed above, when the level of SL was higher than 3\%, SL might aggregate. As a result, PWP with 3\% SL still possessed more hydrophobic residues than PWP as shown in Figure 8C.

\section{CONCLUSIONS}

The data indicated that the interactions between soybean lecithin and WP/PWP occurred in the model system. The interactions may involve in hydrophobic force and electrostatic force, resulting in changes in physicochemical and functional properties of WP.

\section{ACKNOWLEDGMENTS}

This project was financially supported by the Ministry of Science and Technology of China (Project \# 2013BAD18B07).

\section{REFERENCES}

Andoyo, R., F. Guyomarc'H, A. Burel, and M. H. Famelart. 2015. Spatial arrangement of casein micelles and whey protein aggregate in acid gels: Insight on mechanisms. Food Hydrocoll. 51:118-128. https://doi.org/10.1016/j.foodhyd.2015.04.031.

Bourbon, A. I., A. C. Pinheiro, M. A. Cerqueira, and A. A. Vicente. 2016. Influence of chitosan coating on protein-based nanohydrogels properties and in vitro gastric digestibility. Food Hydrocoll. 60:109-118. https://doi.org/10.1016/j.foodhyd.2016.03.002.

Chandrapala, J., B. Zisu, M. Palmer, S. Kentish, and M. Ashokkumar. 2011. Effects of ultrasound on the thermal and structural characteristics of proteins in reconstituted whey protein concentrate. Ultrason. Sonochem. 18:951-957. https://doi.org/10.1016/j.ultsonch .2010.12.016. 
Chiplunkar, P. P., and A. P. Pratap. 2017. Ultrasound assisted synthesis of hydroxylated soybean lecithin from crude soybean lecithin as an emulsifier. J. Oleo Sci. 66:1101-1108. https://doi.org/10.5650/ jos.ess 17090

Creusot, N., and H. Gruppen. 2007. Enzyme-induced aggregation and gelation of proteins. Biotechnol. Adv. 25:597-601. https://doi.org/ 10.1016/j.biotechadv.2007.07.007.

Demetriades, K., and D. J. Mcclements. 1998. Influence of $\mathrm{pH}$ and heating on physicochemical properties of whey protein-stabilized emulsions containing a nonionic surfactant. J. Agric. Food Chem. 46:3936-3942. https://doi.org/10.1021/jf980463c.

Ding, G. J., Y. J. Zhu, C. Qi, B. Q. Lu, F. Chen, and J. Wu. 2015. Porous hollow microspheres of amorphous calcium phosphate: Soybean lecithin templated microwave-assisted hydrothermal synthesis and application in drug delivery. J. Mater. Chem. B Mater. Biol. Med. 3:1823-1830. https://doi.org/10.1039/c4tb01862a.

Eissa, A. S. 2013. Newtonian viscosity behavior of dilute solutions of polymerized whey proteins. Would viscosity measurements reveal more detailed molecular properties? Food Hydrocoll. 30:200-205. https://doi.org/10.1016/j.foodhyd.2012.05.018.

Fitzsimons, S. M., D. M. Mulvihill, and E. R. Morris. 2007. Denaturation and aggregation processes in thermal gelation of whey proteins resolved by differential scanning calorimetry. Food Hydrocoll. 21:638-644. https://doi.org/10.1016/j.foodhyd.2006.07.007.

Homer, S., L. Lundin, and D. E. Dunstan. 2016. Modifying the microstructure and mechanical properties of whey protein isolate gels using large deformation oscillatory strain. Food Hydrocoll. 61:672677. https://doi.org/10.1016/j.foodhyd.2016.06.017.

Ikeda, S., and E. A. Foegeding. 1999a. Dynamic viscoelastic properties of thermally induced whey protein isolate gels with added lecithin. Food Hydrocoll. 13:245-254. https://doi.org/10.1016/S0268 $-005 \mathrm{X}(99) 00006-5$.

Ikeda, S., and E. A. Foegeding. 1999b. Effects of lecithin on thermally induced whey protein isolate gels. Food Hydrocoll. 13:239-244. https://doi.org/10.1016/S0268-005X(99)00005-3.

Jones, M. N. 1992. Surfactant interactions with biomembranes and proteins. Chem. Soc. Rev. 21:127-136. https://doi.org/10.1039/ cs9922100127.

Kato, A., and S. Nakai. 1980. Hydrophobicity determined by a fluorescence probe method and its correlation with surface properties of proteins. Biochim. Biophys. Acta Protein Struct. 624:13-20. https: //doi.org/10.1016/0005-2795(80)90220-2.

Kelley, D., and D. J. Mcclements. 2003. Interactions of bovine serum albumin with ionic surfactants in aqueous solutions. Food Hydrocoll. 17:73-85. https://doi.org/10.1016/S0268-005X(02)00040-1.

Kinsella, J. E., and D. M. Whitehead. 1989. Proteins in whey: Chemical, physical, and functional properties. Adv. Food Nutr. Res. 33:343-438. https://doi.org/10.1016/S1043-4526(08)60130-8.

Kumar, E. K., S. Qumar, and N. P. Prabhu. 2015. Sodium dodecyl sulphate (SDS) induced changes in propensity and kinetics of $\alpha$-lactalbumin fibrillation. Int. J. Biol. Macromol. 81:754-758. https://doi.org/10.1016/j.ijbiomac.2015.09.007.

Kwaambwa, H. M., and A. R. Rennie. 2012. Interactions of surfactants with a water treatment protein from Moringa oleifera seeds in solution studied by zeta-potential and light scattering measurements. Biopolymers 97:209-218. https://doi.org/10.1002/bip.22014.

Le, T. T., P. Sabatino, B. Heyman, M. Kasinos, H. H. Dinh, K. Dewettinck, J. Martins, and P. V. D. Meeren. 2011. Improved heat stability by whey protein-surfactant interaction. Food Hydrocoll. 25:594-603. https://doi.org/10.1016/j.foodhyd.2010.07.012.

Lee, P. E., and W. S. Choo. 2015. Characterization of flaxseed oil emulsions. J. Food Sci. Technol. 52:4378-4386. https://doi.org/10 .1007/s13197-014-1495-3.

Li, J., Y. Li, and S. Guo. 2014. The binding mechanism of lecithin to soybean $11 \mathrm{~S}$ and $7 \mathrm{~S}$ globulins using fluorescence spectroscopy. Food Sci. Biotechnol. 23:1785-1791. https://doi.org/10.1007/ s10068-014-0244-8.

Li, K., and Q. Zhong. 2016. Aggregation and gelation properties of preheated whey protein and pectin mixtures at $\mathrm{pH}$ 1.0-4.0. Food Hydrocoll. 60:11-20. https://doi.org/10.1016/j.foodhyd.2016.03 .009 .
Li, Y., and D. J. Mcclements. 2013. Influence of non-ionic surfactant on electrostatic complexation of protein-coated oil droplets and ionic biopolymers (alginate and chitosan). Food Hydrocoll. 33:368 375. https://doi.org/10.1016/j.foodhyd.2013.04.016.

Liu, X., J. R. Powers, and B. G. Swanson. 2005. Modification of whey protein concentrate hydrophobicity by high hydrostatic pressure. Innov. Food Sci. Emerg. Technol. 6:310-317. https://doi.org/10 $.1016 /$ j.ifset.2005.03.006.

Loiseleux, T., A. Rolland-Sabaté, C. Garnier, T. Croguennec, S. Guilois, M. Anton, and A. Riaublanc. 2017. Determination of hydro-colloidal characteristics of milk protein aggregates using Asymmetrical Flow Field-Flow Fractionation coupled with Multiangle Laser Light Scattering and Differential Refractometer (AF4MALLS-DRi). Food Hydrocoll. 74:197-206. https://doi.org/10 .1016/j.foodhyd.2017.08.012.

Mantovani, R. A., J. Fattori, M. Michelon, and R. L. Cunha. 2016. Formation and $\mathrm{pH}$-stability of whey protein fibrils in the presence of lecithin. Food Hydrocoll. 60:288-298. https://doi.org/10.1016/j .foodhyd.2016.03.039.

Miyasaki, E. K., V. Luccas, and T. G. Kieckbusch. 2015. Modified soybean lecithins as inducers of the acceleration of cocoa butter crystallization. Eur. J. Lipid Sci. Technol. 118:1539-1549. https:// doi.org/10.1002/ejlt.201500093.

Mutilangi, W. A. M., D. Panyam, and A. Kilara. 1996. Functional properties of hydrolysates from proteolysis of heat-denatured whey protein isolate. J. Food Sci. 61:270-275. https://doi.org/10.1111/j .1365-2621.1996.tb14174.x.

Nicolai, T., M. Britten, and C. Schmitt. 2011. $\beta$-Lactoglobulin and WPI aggregates: Formation, structure and applications. Food Hydrocoll. 25:1945-1962. https://doi.org/10.1016/j.foodhyd.2011.02 .006 .

Oechsle, A. M., M. Häupler, M. Gibis, R. Kohlus, and J. Weiss. 2015. Modulation of the rheological properties and microstructure of collagen by addition of co-gelling proteins. Food Hydrocoll. 49:118126. https://doi.org/10.1016/j.foodhyd.2015.03.013.

Ptiček Siročić, A., Lj. Kratofil Krehula, Z. Katančić, and Z. HrnjakMurgić. 2016. Characterization of casein fractions-Comparison of commercial casein and casein extracted from cow's milk. Chem. Biochem. Eng. Q. 30:501-509. https://doi.org/10.15255/CABEQ .2015 .2311

Pugliese, A., M. Paciulli, E. Chiavaro, and G. Mucchetti. 2016. Characterization of commercial dried milk and some of its derivatives by differential scanning calorimetry. J. Therm. Anal. Calorim. 123:2583-2590. https://doi.org/10.1007/s10973-016-5243-y.

Ryan, K. N., B. Vardhanabhuti, D. P. Jaramillo, J. H. V. Zanten, J. N. Coupland, and E. A. Foegeding. 2012. Stability and mechanism of whey protein soluble aggregates thermally treated with salts. Food Hydrocoll. 27:411-420. https://doi.org/10.1016/j.foodhyd 2011.11.006.

Sui, X., S. Bi, B. Qi, Z. Wang, M. Zhang, Y. Li, and L. Jiang. 2017. Impact of ultrasonic treatment on an emulsion system stabilized with soybean protein isolate and lecithin: Its emulsifying property and emulsion stability. Food Hydrocoll. 63:727-734. https://doi .org/10.1016/j.foodhyd.2016.10.024.

Surh, J., E. A. Decker, and D. J. Mcclements. 2006. Influence of $\mathrm{pH}$ and pectin type on properties and stability of sodium-caseinate stabilized oil-in-water emulsions. Food Hydrocoll. 20:607-618. https://doi.org/10.1016/j.foodhyd.2005.07.004.

Taheri-Kafrani, A., E. Asgarimobarakeh, A. K. Bordbar, and T. Haertlé. 2010. Structure-function relationship of beta-lactoglobulin in the presence of dodecyltrimethyl ammonium bromide. Colloids Surf. B Biointerfaces 75:268-274. https://doi.org/10.1016/j .colsurfb.2009.08.045

Tarhan, O., M. J. Spotti, S. Schaffter, C. M. Corvalan, and O. H. Campanella. 2016. Rheological and structural characterization of whey protein gelation induced by enzymatic hydrolysis. Food Hydrocoll. 61:211-220. https://doi.org/10.1016/j.foodhyd.2016.04 .042 .

Thomas, M. E., J. Scher, and S. Desobry. 2004. Lactose/beta-lactoglobulin interaction during storage of model whey powders. 
J. Dairy Sci. 87:1158-1166. https://doi.org/10.3168/jds.S0022 -0302(04)73264-6.

Verheul, M., and S. P. F. M. Roefs. 1999. Structure of particulate whey protein gels: Effect of $\mathrm{NaCl}$ concentration, $\mathrm{pH}$, heating temperature, and protein composition. J. Agric. Food Chem. 46:49094916. https://doi.org/10.1021/jf981100f.

Viseu, M. I., E. P. Melo, T. I. Carvalho, R. F. Correia, and S. M. Costa. 2007. Unfolding kinetics of beta-lactoglobulin induced by surfactant and denaturant: A stopped-flow/fluorescence study. Biophys. J. 93:3601-3612. https://doi.org/10.1529/biophysj.106 .101667 .

Vissotto, F. Z., F. M. Montenegro, J. M. Santos, and S. J. R. Oliveira 2006. Avaliação da influência dos processos de lecitinação e de aglomeração nas propriedades físicas de achocolatado em pó. Food Sci. Technol. (Campinas) 26:666-671. https://doi.org/10.1590/ S0101-20612006000300028

Wang, C., F. Gao, T. Zhang, Y. Wang, and M. Guo. 2015. Physiochemical, textural, sensory properties and probiotic survivability of Chinese Laosuan Nai (protein-fortified set yoghurt) using polymerised whey protein as a co-thickening agent. Int. J. Dairy Technol. 68:261-269. https://doi.org/10.1111/1471-0307.12186.

Wang, S., Y. Shi, Z. Tu, L. Zhang, H. Wang, M. Tian, and N. Zhang. 2017b. Influence of soy lecithin concentration on the physical properties of whey protein isolate-stabilized emulsion and microcapsule formation. J. Food Eng. 207:73-80. https://doi.org/10.1016/j .jfoodeng.2017.03.020.

Zhang, L., J. Song, G. Cavigiolio, B. Y. Ishida, S. Zhang, J. P. Kane, K. H. Weisgraber, M. N. Oda, K. A. Rye, and H. J. Pownall. 2011 Morphology and structure of lipoproteins revealed by an optimized negative-staining protocol of electron microscopy. J. Lipid Res. 52:175. https://doi.org/10.1194/jlr.D010959.

Zhang, S., and B. Vardhanabhuti. 2014. Effect of initial protein concentration and $\mathrm{pH}$ on in vitro gastric digestion of heated whey proteins. Food Chem. 145:473-480. https://doi.org/10.1016/j .foodchem.2013.08.076. 